\title{
Changes in ecosystem service values strongly influenced by human activities in contrasting agro-ecological environments
}

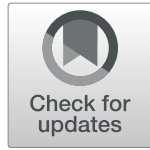

Mulatu Liyew Berihun ${ }^{1,2^{*}}$ (D, Atsushi Tsunekawa ${ }^{2}$, Nigussie Haregeweyn ${ }^{3}$, Mitsuru Tsubo $^{2}$ and Ayele Almaw Fenta ${ }^{2}$

\begin{abstract}
Background: Evaluating the impacts of land-use/land-cover (LULC) changes on ecosystem service values (ESVs) is essential for sustainable use and management of ecosystems. In this study, we evaluated the impact of human activity driven LULC changes on ESVs over the period 1982-2016/17 in contrasting agro-ecological environments: Guder (highland), Aba Gerima (midland), and Debatie (lowland) watersheds of the Upper Blue Nile basin, Ethiopia.

Results: During the study period, the continuous expansion of cultivated land at the expense of natural vegetation (bushland, forest, and grazing land) severely reduced the total ESV by about US\$ 58 thousand (35\%) in Aba Gerima and US\$ 31 thousand (29\%) in Debatie watersheds. In contrast, the unprecedented expansion of plantations, mainly through the planting of Acacia decurrens, led, from 2006, to a ESV rebound by about US\$ 71 thousand (54\%) in Guder watershed, after it had decreased by about US\$ 61 thousand (32\%) between 1982 and 2006. The reduction in natural forest area was the major contributor to the loss of total ESV in the study watersheds, ranging from US\$ 31 thousand (63\%) in Debatie to US\$ 96.9 thousand (70\%) in Guder between 1982 and 2016/17. On an areaspecific basis, LULC changes reduced the average ESV from US\$560 ha ${ }^{-1}$ year $^{-1}$ (1982) in Guder to US\$ 306 ha $^{-1}$ year $^{-1}$ (2017) in Debatie watersheds. Specific ESVs such as provisioning (mainly as food production) and regulating services (mainly as erosion control and climate regulation) accounted for most of the total ESVs estimated for the study watersheds.

Conclusions: In most cases, the total and specific ESVs of the watersheds were negatively associated with the population growth, which in turn was positively associated with the expansion of cultivated land over the study period. In Guder, however, ESVs were positively associated with population growth, especially after 2012. This is mainly due to the expansion of Acacia decurrens plantations. Our results suggest, therefore, that future policy measures and directions should focus on improving vegetation cover through planting multipurpose trees such as Acacia decurrens to prevent future loss of ESV in the midland and lowland regions of the Upper Blue Nile basin and beyond. However, caution must be taken during plantation of invasive species as they may have undesirable consequences.
\end{abstract}

Keywords: Drought prone, Agro-ecologies, Land use/land cover, Acacia decurrens, Plantations, Ecosystem services, Farming practices, Upper Blue Nile basin

\footnotetext{
* Correspondence: mulatuliyew@yahoo.com

'Faculty of Civil and Water Resources Engineering, Bahir Dar Institute of

Technology, Bahir Dar University, P.O. Box 26, Bahir Dar, Ethiopia

${ }^{2}$ Arid Land Research Center, Tottori University, 1390 Hamasaka, Tottori

680-0001, Japan

Full list of author information is available at the end of the article
}

\section{Springer Open}

(c) The Author(s). 2021 Open Access This article is licensed under a Creative Commons Attribution 4.0 International License, which permits use, sharing, adaptation, distribution and reproduction in any medium or format, as long as you give appropriate credit to the original author(s) and the source, provide a link to the Creative Commons licence, and indicate if changes were made. The images or other third party material in this article are included in the article's Creative Commons licence, unless indicated otherwise in a credit line to the material. If material is not included in the article's Creative Commons licence and your intended use is not permitted by statutory regulation or exceeds the permitted use, you will need to obtain permission directly from the copyright holder. To view a copy of this licence, visit http://creativecommons.org/licenses/by/4.0/. 


\section{Introduction}

Land-use/land-cover (LULC) changes induced by human activity are a major challenge facing the global environment (Wilbanks and Kates 1999). These changes alter hydrological responses (Haregeweyn et al. 2016; Fenta et al. 2017; Berihun et al. 2019a), biodiversity and ecosystem processes and services (Lambin et al. 2003; Goldewijk and Ramankutty 2004; Maitima et al. 2009), and challenge conservation management and rehabilitation activities (e.g., Fenta et al. 2016; Berihun et al. 2019b; Haregeweyn et al. 2019; Berihun et al. 2020; Fenta et al. 2021).

Ecosystem services consist of the benefits that people obtain from biodiversity and ecosystems and are increasingly recognized as being important for maintaining and fulfilling human well-being (Millennium Ecosystem Assessment [MEA] 2005). The MEA (2005) also noted that $60 \%$ of the world's ecosystems are degraded, leading to a reduction in their services to humans. Because of population pressure and associated human activities such as agriculture, firewood consumption, deforestation, and urbanization, LULC dynamics is the main driver behind ecosystem degradation and changes in ecosystem services (Costanza et al. 1997; Hu et al. 2008; de Groot et al. 2012; Costanza et al. 2014; Kindu et al. 2016; Wang et al. 2017; Cheng et al. 2018; Lin et al. 2018; Mamat et al. 2018; Liu et al. 2019; Fenta et al. 2020; Negash et al. 2020). Costanza et al. (2014) reported that global LULC changes induced declines in ecosystem service values (ESVs) from US\$ 145 trillion year ${ }^{-1}$ in 2007 to US\$ 125 trillion year ${ }^{-1}$ in 2011. As a result of LULC changes, the loss of ESVs at a global scale also ranged from about US\$4-20 trillion year ${ }^{-1}$ between 1997 and 2011 (de Groot et al. 2012; Costanza et al. 2014). However, the variations in ESVs have not been uniform worldwide (Costanza et al. 2014) largely because of variations in LULC dynamics (Lambin et al. 2003; Goldewijk and Ramankutty 2004). For example, there has been an improvement in ecosystem services in developed countries (e.g., $\mathrm{Hu}$ et al. 2008; Li et al. 2018; Wang et al. 2018) resulting from the conversion of crop production to forests, whereas in most of the developing countries like Ethiopia, certain ecosystem services have the highest rate of loss (e.g., Kindu et al. 2016; Gashaw et al. 2018).

The loss of ESVs induced by LULC changes are also major environmental challenges in Ethiopia (e.g., Kindu et al. 2016; Tolessa et al. 2017a, 2017b; Gashaw et al. 2018; Negash et al. 2020), where agricultural activity is the backbone of the economy. Previous studies have shown a notable reduction of ESVs in different parts of the country due to the expansion of cultivated land, mainly through deforestation activities. For example, studies by Gashaw et al. (2018) in Andassa watershed in the Upper Blue Nile basin from 1985 to 2015, Kindu et al. (2016) in the Munessa-Shashemene landscape
(1973-2012), Negash et al. (2020) in north-central Ethiopia (1973-2001), and Tolessa et al. (2017b) in the Chilimo forest (central highlands of Ethiopia; 19732015) show that the expansion of cultivated land at the expense of natural vegetation (mainly as forest land, grazing land, and shrubland) substantially reduces the value of the land's ecosystem services. However, through restoration of the landscape, ESVs had recovered by 2016 in north-central Ethiopia (Negash et al. 2020).

Because there are few local specific studies of ESVs in Ethiopia, it is difficult to generalize any ESV trends, even within a specific region such as the Upper Blue Nile basin, mainly because of the influence of the various human activities on LULC change and the agro-ecological settings of the watersheds. The different agro-ecological settings control population growth, settlement characteristics, and economic activities, thereby affecting the LULC dynamics (Berihun et al. 2019a; Gebrehiwot et al. 2014), which is a major cause of changes in ESVs (Costanza et al. 1997; Wu et al. 2013; Costanza et al. 2014; Hou et al. 2014; Wang et al. 2015; Cheng et al. 2018; Wondie and Mekuria 2018; Yuan et al. 2018; Liu et al. 2019). Most of the previous studies in Ethiopia (e.g., Kindu et al. 2016; Tolessa et al. 2017a, 2017b; Gashaw et al. 2018; Negash et al. 2020) evaluated the changes in ESVs resulting from LULC change by considering only specific watersheds with a single agro-ecological environment and uniform human activity, such as increasing demand for agricultural land. The evaluation of ESVs in different agro-ecologies and for a variety of human activities is therefore rare in Ethiopia in general and in the Upper Blue Nile basin in particular, where there is a greater diversity of ecosystem services. Thus, agro-ecology-based, watershed-specific ESV estimates are vital for quantifying the overall ecosystem services in Ethiopia at wider temporal and spatial scales.

Estimation of ESVs using LULC data and ESV coefficients is extremely vital in Ethiopia, despite the expensiveness of ground data (Kindu et al. 2016; Tolessa et al. 2017a, 2017b). Furthermore, quantifying the impacts of human-induced LULC dynamics on ESV changes is important for determining the vulnerability of each ecosystem service, thereby providing alternatives and robust information for decision-making at the landscape level to ensure the sustainability of natural resources and fulfil sustainable development goals (Wu et al. 2013; Costanza et al. 2014; Hou et al. 2014; Wang et al. 2017;Cheng et al. 2018; Mamat et al. 2018; Chen et al. 2020). Therefore, in this study, we evaluated the spatial and temporal responses of ESVs to historical LULC changes in strongly human-impacted watersheds located in contrasting agro-ecological environments of the Upper Blue Nile basin. Following the recommendation of Mamat et al. (2018), and unlike many previous studies in 
Ethiopia and elsewhere that mainly used Landsat images (e.g., Kindu et al. 2016; Tolessa et al. 2017a, 2017b; Gashaw et al. 2018; Liu et al. 2019; Negash et al. 2020), we used very high resolution remote-sensing satellite data (e.g., Pleiades, IKONOS-2, Quick Bird; 0.5- to 3.2$\mathrm{m}$ resolution; Berihun et al. 2019a) to improve the accuracy of LULC classification, which was then used to estimate the ESVs of the watersheds.

\section{Materials and methods}

\section{Study area}

The study watersheds were located in the Upper Blue Nile basin of northwestern Ethiopia (Fig. 1). These watersheds were purposefully selected to represent three different agro-ecological environments of the Upper Blue Nile basin-highland (Guder), midland (Aba Gerima), and lowland (Debatie)—classified based on topographical and hydro-meteorological characteristics of the study areas, as summarized in Table TS1 (Hurni et al. 2016).

Each agro-ecological environment is characterized by specific topographical features, climate conditions, major soil types, soil and water conservation practices, and dominant agricultural practices (Table TS1). As described above as shown Fig. 1, the elevations range from 1501 to 2857 m.a.s.l. at Debatie and Guder, respectively. The slopes were generated from Shuttle Radar Topography Mission digital elevation model (SRTM-DEM) data and reclassified as flat $(0-3 \%)$, gentle $(3-8 \%)$, sloping $(8-15 \%)$, steep $(15-30 \%)$, and very steep (>30\%). The study watersheds included substantial areas predominantly characterized as steep (Guder, $40 \%$ of the area; Debatie, 36.4\%) or sloping (Aba Gerima, 38.5\% of the area). These steep slope areas are mostly covered by forest or other natural vegetation whereas the areas categorized under flat and gently sloping are mainly used for cultivated land and settlements.

Based on the field-based soil analysis reports, the dominant soil types in three study watersheds are Luvisols, Acrisols, Leptosols, and Vertisols (Mekonnen 2018). All four major soil types occur in Guder watershed, whereas only Luvisols, Vertisols, and Leptosols are present in Debatie and Luvisols and Leptosols in Aba Gerima watersheds. The long-term (1982-2016) mean annual rainfall generally increased in the order of Debatie < Aba Gerima $<$ Guder watersheds (Berihun et al. 2019b). More than $86 \%$ of the total rainfall is concentrated during the rainy seasons (June-September) in the three study watersheds (Berihun et al. 2019b). A mixed crop-livestock farming system provides the dominant livelihood for farmers in the study watersheds (Table S1; Abeje et al. 2019).

Land-use/land-cover changes between 1982 and 2016/17 The historical changes in LULC of the watersheds were compiled from the previous work by Berihun et al. (2019a). Aerial photographs (1:50,000 scale; purchased from Ethiopia Mapping Agency) and orthorectified very high-resolution multi-scale satellite images (IKONOS-2, QuickBird, Pleiades, WorldView-2; resolutions ranging from 0.5 to $3.2 \mathrm{~m}$; purchased from AIRBUS defense and space) were used for LULC classification for the study periods of 1982, 2005/06, 2011/12, and 2016/17 (Table S2; Berihun et al. 2019a). We applied intensive visual interpretations and on-screen digitization technique using ArcGIS 10.4 for LULC mapping and classification processes. Thus, for each watershed, we identified from four to six LULC classes for each study period (Table TS2, S3).

For some analyses, the LULC classes were further grouped into two classes: vegetation cover (bushland, forest land, grazing, and plantation) and cultivated land. The extent of the changes and conversion trends of LULC classes occurring between study periods were estimated by conversion matrix analysis using an overlay procedure (Berihun et al. 2019a).

In 1982, the LULC change results showed that forest land was the dominant LULC class, respectively, accounting for $40.9 \%$ and $32.0 \%$ of the area in Guder and Aba Gerima watersheds (Fig. FS1, Table TS3). During the same period, in Debatie watershed, bushland (36.6\%) was the dominant LULC class (Fig. FS, Table TS3). Natural vegetation cover such as forest land, bushland, and grazing land decreased by about $70 \%, 50 \%$, and $27 \%$ in Guder; by $65 \%, 49 \%$, and $63 \%$ in Aba Gerima; and by $63 \%, 59 \%$, and 38\% in Debatie, respectively from 1982 to 2016/17 (Fig. 2).

Similarly, khat (Catha edulis) cultivation LULC class increased from 2005 to 2016 by more than $400 \%$ in Aba Gerima watershed, mainly at the expense of cultivated land (Fig. 2). Moreover, in all study watersheds, settlement LULC class accounted for the least coverage compared to other LULC classes, occupying less than $5 \%$ of the area (Table TS3) while it showed a dramatic increasing trend over the study periods (Fig. 2).

The increasing or decreasing of LULC classes between the study periods could have socio-economic implications. In the study watersheds, traditional farming practices is the backbone of the economy, and the community is highly dependent on rainfed agriculture system. Thus, the expansion of cultivated and grazing lands could possibly have negative and positive consequences on the livelihood of the communities. For instance, although the expansion of cultivated land at the expense of natural vegetations for crop productions will have advantages to solve the food security challenges in the area, it could have negative consequences in the future by aggravating the soil erosion process in the area as compared with natural vegetation (Berihun et al. 2020). Also, the substantial conversion of grazing land to plantation in Guder and cultivated land in the three 


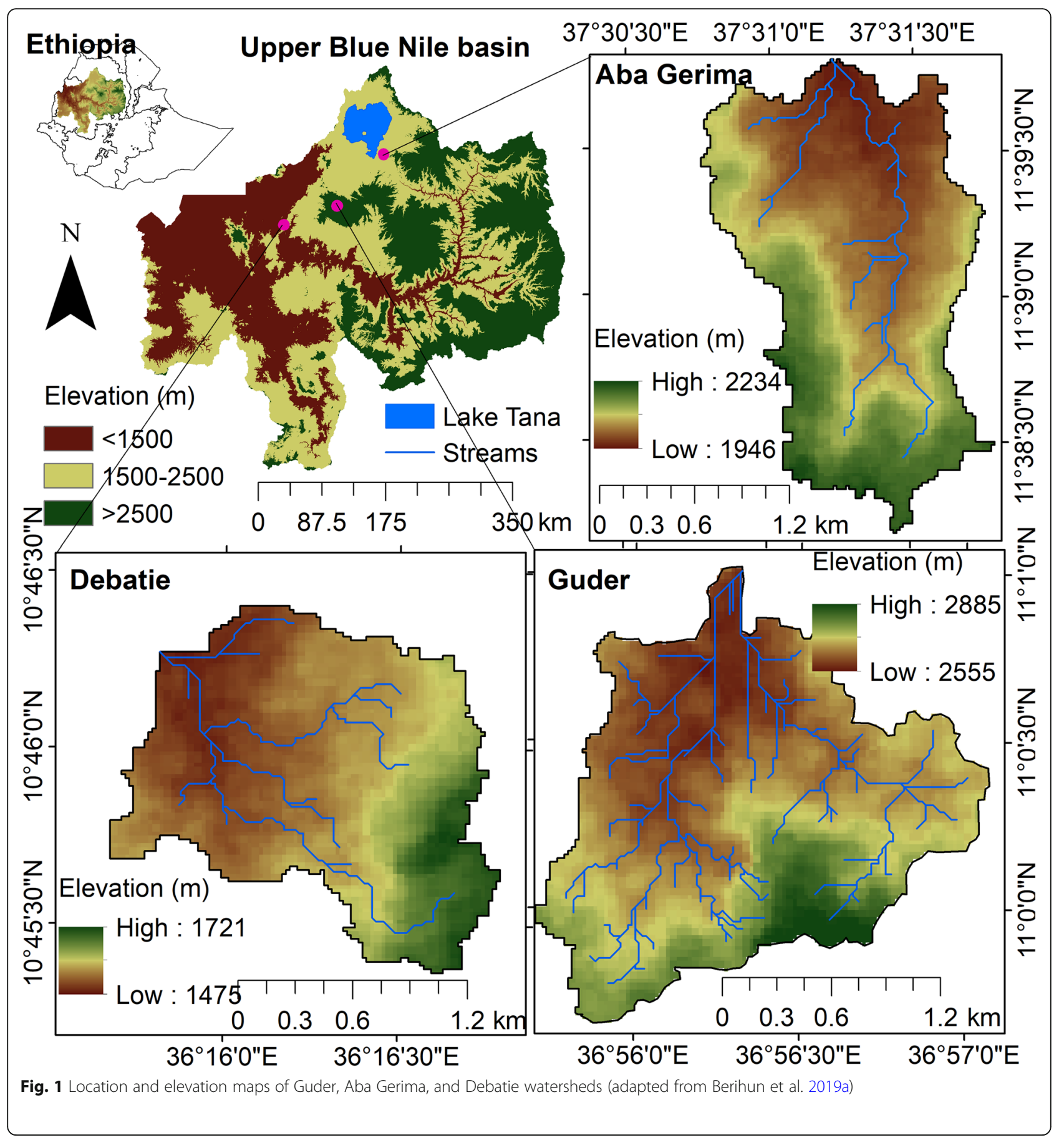

study watersheds (Table TS4-TS6) is likely to have negative consequences on the existing free-grazing feeding system and consequently on the number of livestock. In general, the conversions of one LULC to other LULC class could have socio-economic and environmental implications in the study area. Details of the temporal and spatial extents, changes, and conversion matrices of each LULC class in the three study watersheds can be found in the Supplementary Materials (Tables TS4-TS6) and in Berihun et al. (2019a).

\section{Estimation of ESVs}

For Guder and Debatie watersheds, we assessed the changes in ESVs using the LULC classification data over four study periods (1982, 2006, 2011/12, and 2017). For Aba Gerima watershed, we used three study periods 

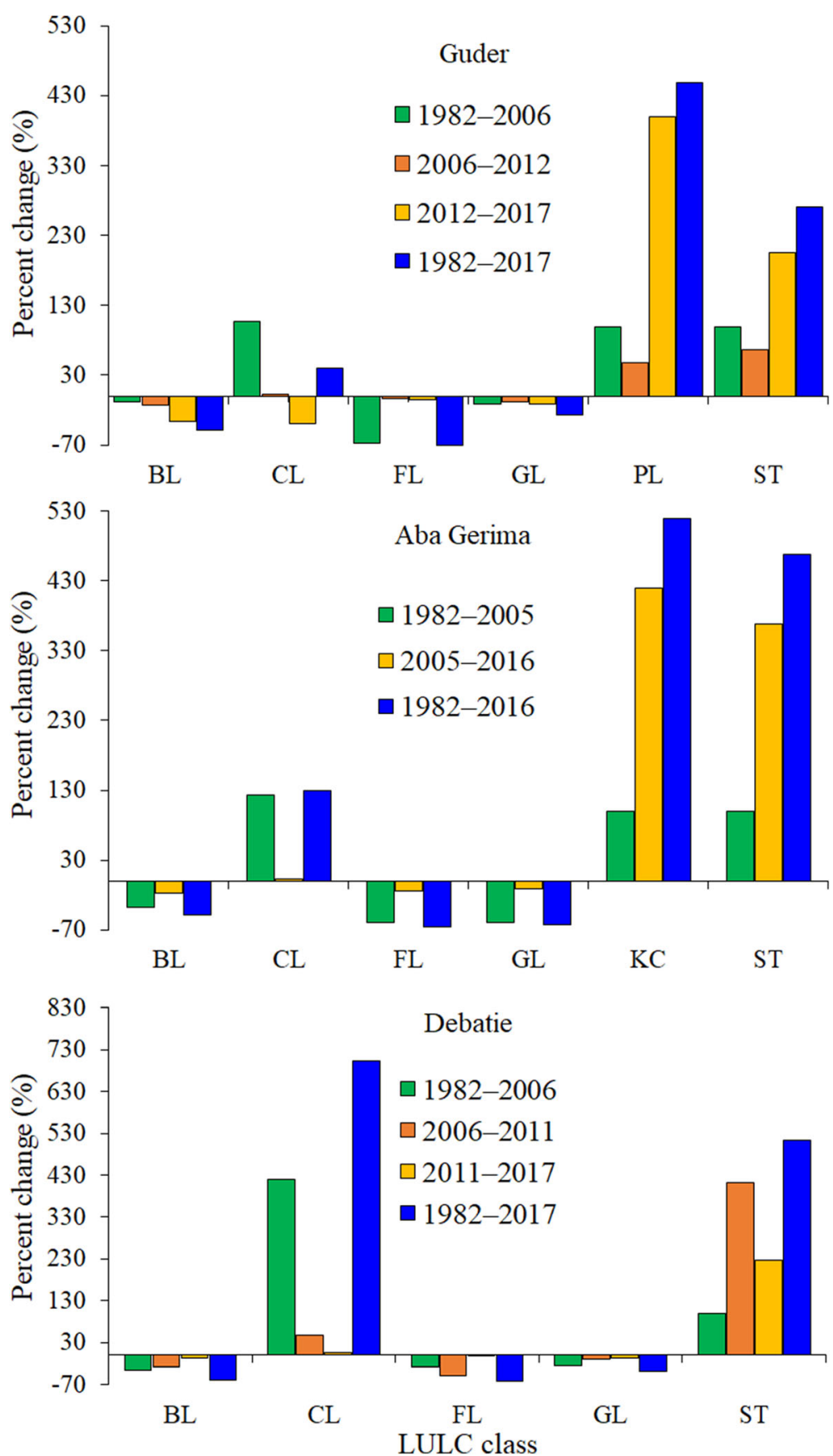

Fig. 2 Percent change (\%) in land-use/land-cover (LULC) classes for Guder, Aba Gerima, and Debatie watersheds, Ethiopia (LULC abbreviations as defined in Table TS3)

(1982, 2005, and 2016) because of a lack of 2011/12 satellite images. The ESVs were estimated using local modified ESV coefficients (Kindu et al. 2016) developed for 6 Ethiopian biomes based on Costanza et al. (1997); the LULC classes of the study watersheds were associated with the corresponding representative biomes (Tables 1 and 2). Following the procedure of Knoke et al. (2011), the ESV coefficients of Kindu et al. (2016) were modified through a benefit transfer method with the applicability of the transferred data validated by applying the Economics of Ecosystems and Biodiversity valuation database (van der Ploeg and de Groot 2010) to the studied landscape conditions, considering values from tropical areas for LULC classes. The transferred value coefficients were also adjusted using the consumer price index and producer price index to check the time- 
Table 1 Biome equivalents for land-use/land-cover (LULC) classes and the corresponding ecosystem service value (ESV) coefficients based on the modified estimates of Kindu et al. (2016)

\begin{tabular}{lll}
\hline LULC class & $\begin{array}{l}\text { Equivalent } \\
\text { biome }\end{array}$ & $\begin{array}{l}\text { ESV coefficients } \\
\text { (US\$ ha } \text { hear }^{-1} \text { ) }\end{array}$ \\
\hline Bushland/Khat cultivation & Tree patches & 293.3 \\
Cultivated land & Cropland & 225.6 \\
Forest land & Tropical forest & 986.7 \\
Grazing land & Grassland & 293.3 \\
Plantation forest & Tropical forest & 986.7 \\
Settlements & Urban & 000.0 \\
\hline
\end{tabular}

dependence of the coefficients on the overall estimation of ESV changes (Kindu et al. 2016).

It is worth noting that some LULC classes did not align exactly with the representative biomes. However, these biomes can be used as proxies for estimating ESVs of the study watersheds, as they have been considered in previous studies in Ethiopia (e.g., Gashaw et al. 2018; Kindu et al. 2016; Negash et al. 2020; Tolessa et al. 2017a, 2017b ) and elsewhere (e.g., Wu et al. 2013; Yi et al. 2017; Wang et al. 2018; Ye et al. 2018; Yuan et al. 2018).

The ESV per unit area for each LULC class was estimated using the following equations developed by Costanza et al. (1997):

$$
\begin{aligned}
& E S V_{k}=\sum\left(A_{k} * V C_{k}\right) \\
& E S V_{f}=\sum\left(A_{k} * V C_{f k}\right)
\end{aligned}
$$

Percent ESV change (\%)

$$
=\left(\frac{E S V_{\text {year } 2}-E S V_{\text {year } 1}}{E S V_{\text {year } 1}}\right) \text {, }
$$

where $E S V_{k}$ is the ESV of LULC class $k$ in a given year, $A_{k}$ is the area (ha) of LULC class $k, V C_{k}$ is the value coefficient of LULC class $k$ (US\$ ha ${ }^{-1}$ year $^{-1}$ ), $E S V_{f}$ is estimated ESV service function $f$ in a given year, and $V C_{f k}$ is the value coefficient of function $f$ (US\$ ha ${ }^{-1}$ year $^{-1}$ ) for LULC class $k$. The modified coefficients that were used in this study are presented in Tables 2 and 3.

The total ESV for each watershed was estimated by summing the $E S V_{k}$ estimates, and the values of 17

\begin{tabular}{|c|c|c|c|c|c|}
\hline \multirow[t]{2}{*}{ Ecosystem services } & \multicolumn{5}{|c|}{ Each LULC classes ecosystem service values (US\$ ha ${ }^{-1}$ year $^{-1}$ ) } \\
\hline & Natural forest & Plantation forest & Cropland & Grasslands & Tree patches \\
\hline \multicolumn{6}{|l|}{ Provisioning services } \\
\hline Water supply & 8.0 & 8.0 & - & - & - \\
\hline Food production & 32.0 & 32.0 & 187.6 & 117.5 & 117.5 \\
\hline Raw material & 51.2 & 51.2 & - & - & - \\
\hline Genetic resources & 41.0 & 41.0 & - & - & - \\
\hline \multicolumn{6}{|l|}{ Regulating services } \\
\hline Water regulation & 6.0 & 6.0 & - & 3.0 & 3.0 \\
\hline Water treatment & 136.0 & 136.0 & - & 87.0 & 87.0 \\
\hline Erosion control & 245.0 & 245.0 & - & 29.0 & 29.0 \\
\hline Climate regulation & 223.0 & 223.0 & - & - & - \\
\hline Biological control & - & - & 24.0 & 23.0 & 23.0 \\
\hline Gas regulation & 13.7 & 13.7 & - & 7.0 & 7.0 \\
\hline Disturbance regulation & 5.0 & 5.0 & - & - & - \\
\hline \multicolumn{6}{|l|}{ Supporting services } \\
\hline Nutrient cycling & 184.4 & 184.4 & - & - & - \\
\hline Pollination & 7.3 & 7.3 & 14.0 & 25.0 & 25.0 \\
\hline Soil formation & 10.0 & 10.0 & - & 1.0 & 1.0 \\
\hline Habitat/refugia & 17.3 & 17.3 & - & - & - \\
\hline \multicolumn{6}{|l|}{ Cultural services } \\
\hline Recreation & 4.8 & 4.8 & - & 0.8 & 0.8 \\
\hline Cultural & 2.0 & 2.0 & - & - & - \\
\hline Total & 986.7 & 986.7 & 225.6 & 293.3 & 293.3 \\
\hline
\end{tabular}

Table 2 Individual ecosystem service value coefficients (US $\$ \mathrm{ha}^{-1} \mathrm{year}^{-1}$ ) for the five representative biomes based on the modified estimates of Kindu et al. (2016) 
Table 3 Effect of changes in land-use/land-cover (LULC) on the total ecosystem service value (ESV; US\$ [thousands], \%) in Guder, Aba Gerima, and Debatie watersheds, Ethiopia. LULC abbreviations as defined in Table TS2

\begin{tabular}{|c|c|c|c|c|c|c|c|c|c|}
\hline \multirow[t]{2}{*}{ Watershed } & \multirow{2}{*}{$\begin{array}{l}\text { LULC } \\
\text { class }^{a}\end{array}$} & \multicolumn{2}{|l|}{1982} & \multicolumn{2}{|c|}{$2005 / 06$} & \multicolumn{2}{|c|}{$2011 / 12$} & \multicolumn{2}{|c|}{$2016 / 17$} \\
\hline & & ESV & (\%) & $\overline{\text { ESV }}$ & (\%) & $\overline{E S V}$ & (\%) & ESV & (\%) \\
\hline \multirow[t]{7}{*}{ Guder } & $B L$ & 16.1 & 8.4 & 14.8 & 11.2 & 12.9 & 9.5 & 8.2 & 4.0 \\
\hline & $\mathrm{CL}$ & 18.8 & 9.8 & 38.9 & 29.6 & 39.9 & 29.4 & 23.9 & 11.8 \\
\hline & $\mathrm{FL}$ & 138.5 & 72.0 & 45.6 & 34.6 & 44.1 & 32.5 & 41.6 & 20.6 \\
\hline & $\mathrm{GL}$ & 19.0 & 9.9 & 16.9 & 12.8 & 15.6 & 11.5 & 13.8 & 6.8 \\
\hline & $P L$ & 0.0 & 0.0 & 15.6 & 11.8 & 23.0 & 17.0 & 114.9 & 56.8 \\
\hline & ST & - & 0.0 & - & 0.0 & - & 0.0 & - & 0.0 \\
\hline & Total & 192.4 & 100.0 & 131.8 & 100.0 & 135.5 & 100.0 & 202.4 & 100.0 \\
\hline \multirow[t]{7}{*}{ Aba Gerima } & $B L$ & 26.6 & 16.0 & 16.6 & 14.7 & - & - & 13.6 & 12.6 \\
\hline & $\mathrm{CL}$ & 21.9 & 13.2 & 48.8 & 43.1 & - & - & 50.2 & 46.5 \\
\hline & $\mathrm{FL}$ & 105.7 & 63.7 & 42.5 & 37.5 & - & - & 36.7 & 33.9 \\
\hline & $\mathrm{GL}$ & 11.7 & 7.0 & 4.8 & 4.2 & - & - & 4.3 & 4.0 \\
\hline & $\mathrm{KC}$ & 0.0 & 0.0 & 0.5 & 0.4 & - & - & 3.3 & 3.1 \\
\hline & ST & - & 0.0 & - & 0.0 & - & - & - & 0.0 \\
\hline & Total & 165.8 & 100.0 & 113.2 & 100.0 & - & - & 108.1 & 100.0 \\
\hline \multirow[t]{6}{*}{ Debatie } & $B L$ & 26.5 & 25.0 & 16.6 & 18.1 & 11.9 & 15.6 & 10.9 & 14.5 \\
\hline & $\mathrm{CL}$ & 3.7 & 3.5 & 19.4 & 21.2 & 28.6 & 37.3 & 30.1 & 39.8 \\
\hline & $\mathrm{FL}$ & 49.5 & 46.6 & 35.9 & 39.1 & 18.4 & 24.0 & 18.3 & 24.2 \\
\hline & $\mathrm{GL}$ & 26.3 & 24.8 & 19.8 & 21.6 & 17.7 & 23.1 & 16.2 & 21.5 \\
\hline & ST & - & 0.0 & 0.0 & 0.0 & 0.0 & 0.0 & 0.0 & 0.0 \\
\hline & Total & 106.1 & 100.0 & 91.8 & 100.0 & 76.5 & 100.0 & 75.6 & 100.0 \\
\hline
\end{tabular}

individual ecosystem services (Table 2) were also estimated using Eq. 2. The above methods for estimating ESVs have been employed in previous studies in Ethiopia and elsewhere (e.g., Kindu et al. 2016; Tolessa et al. 2017a, 2017b; Yi et al. 2017; Gashaw et al. 2018; Negash et al. 2020). We also estimated the average ESVs of the land (US\$ ha ${ }^{-1}$ year $^{-1}$ ) in the three study watersheds for each study period by dividing the total ESV (US\$ year ${ }^{-1}$ ) during a specific year by the watershed area (ha).

\section{Variations in ESVs in response to human actvities}

We examined the variations of ESVs in the three study watersheds in response to human activities such as those associated with population growth and changing farming practices. We collected population data for three periods: for 1994 and 2007 from the Ethiopia Census Report (Central Statistical Authority [CSA] 1994, 2007), and for 2016 from the local kebele administration offices. It was not possible to obtain population data that applied specifically to the respective watersheds because the data were assembled according to different administrative boundaries. Therefore, only the kebele-level population data whose area fell within the study watersheds were considered for the analysis. However, the population number for 1982 was extrapolated using the exponential growth rate relationship (Eqs. 4 and 5) recommended by the Ethiopian CSA, because there were no kebele-level census data available before 1994.

$$
\begin{aligned}
& P_{2}=P_{1} e^{r t} \\
& r=\frac{1}{n} \ln \left(\frac{P_{2}}{P_{1}}\right) \times 100
\end{aligned}
$$

where $P_{1}$ is the population at time $1, P_{2}$ is the population at time $2, r$ is the percent growth rate, and $t$ is the number of years between time 1 and time 2 .

Therefore, to better understand the effect of human activities on LULC change, we first reclassified the six major land use types into two categories: cultivated land and vegetation cover (including grazing land, bush land, forest land, and plantation). The relationship between changes in these two LULC categories and population number was established for the years 1982, 1994, 2007, and 2016. Furthermore, we investigated the effect of changing farming practices, particularly the introduction of Acacia decurrens in Guder watershed and khat cultivation in Aba Gerima watershed, on the change in total and specific ESVs based on observed LULC change (as vegetation cover and cultivated land), interviews and 
reviewing relevant studies conducted in our study areas and elsewhere.

\section{Results and discussion}

Temporal and spatial changes in total ESV

In Guder watershed, the total ESV decreased from US\$ 192.4 thousand in 1982 to US\$ 131.8 thousand in 2006, whereas it increased to US\$202.4 thousand in 2017 (Table 3). From 1982 to 2012, the contribution of forest to the total ESV fell from 72 to $32.5 \%$, a change greater than for the other LULC classes. However, the lost contribution of forest to the total ESV was replaced by plantation land (mainly through $A$. decurrens) by 2017, which accounted for about 57\% (US\$ 114.9 thousand) of the total ESV (Table 3). Cultivated land was the second highest overall contributor to total ESV (9.8$29.6 \%)$ followed by grazing land $(6.8-12.8 \%)$ and bushland (4-11.2\%) over the study period (1982-2017; Table 3).

In Aba Gerima watershed, the total ESV decreased from US\$ 165.8 thousand in 1982 to US\$ 113.2 thousand in 2005 and US\$ 108.1 thousand in 2016 (Table 3). The contribution of cultivated land and forest to the total ESV was about $77-81 \%$ in all study periods. Cultivated land was the major contributor in 2005 and 2016, followed by forest, which was the major contributor in 1982 by a wide margin (Table 3). In this watershed, the contributions of bushland, forest, and grazing land to the total ESV decreased from 1982 to 2016, whereas the contribution of cultivated land increased by 2005 and that of khat cultivation increased after 2005 (Table 3).

Like Aba Gerima watershed, the total ESV continuously decreased from 1982 to 2017. For 1982 and 2006, forest was the major contributor to the total ESV (46.6\% in 1982 and 39.1\% in 2006; Table 3, Fig. 3). However, in 2011 and 2017, cultivated land was the largest contributor and accounted for $37.3 \%$ and $39.8 \%$, respectively. In both of these periods, forest was the second contributor after cultivated land, with a share of $24 \%$ of the total ESV (Table 3, Fig. 3).

On the other hand, in Guder watershed, the average ESV of the land was reduced from about US\$ $560 \mathrm{ha}^{-1}$ year $^{-1}$ in 1982 to US\$ $384 \mathrm{ha}^{-1}$ year $^{-1}$ in 2006 , whereas it increased from about US\$ 394 $\mathrm{ha}^{-1}$ year $^{-1}$ in 2012 to US\$ $589 \mathrm{ha}^{-1}$ year $^{-1}$ in 2017 (Fig. 3). On the other hand, the LULC changes from 1982 to 2016/17-mainly the expansion of cultivated land at the expense of natural vegetation-reduced the average ESV of the land from about US\$ 495 to US\$ $323 \mathrm{ha}^{-1}$ year $^{-1}$ in Aba Gerima watershed and from US\$ 429 to US\$ $306 \mathrm{ha}^{-1}$ year $^{-1}$ in Debatie watershed (Fig. 3). Overall, throughout the study period the average ESV of the land ranged from US\$ 306 ha $^{-1}$ year $^{-1}$ in Debatie watershed to US\$ 560 ha $^{-1}$ year $^{-1}$ in Guder watershed.

In general, our results indicate that the total ESV decrease from 1982 to 2012 in Guder (highland) watershed (Tables 4 and 5) mainly resulted from the conversion of forest and grazing land to cultivated land (Table TS3); whereas from 2006 to 2017, the total ESV recovered by US\$ 70.6 thousand (54\%) as a result of unprecedented expansion of $A$. decurrens plantations, converted from cultivated and grazing lands. Likewise, the decline in total ESV by US\$ 57.7 thousand (35\%) in Aba Gerima (midland) watershed (Tables 4 and 5) was because of the continuous conversion of forest to cultivated land from 1982 to 2005, as well as the conversion of bushland and grazing land to cultivated land after 2005 (Berihun et al. 2019a). The decline of total ESV by US $\$ 30.5$ thousand (29\%) in Debatie (lowland) watershed resulted from the pronounced conversion of bushland and grazing land to cultivated land over the entire study period (1982-2017).

The continuous decline of ESVs in Guder watershed from 1982 to 2012 and in Aba Gerima and Debatie watersheds from 1982 to 2016/17, mainly through the loss

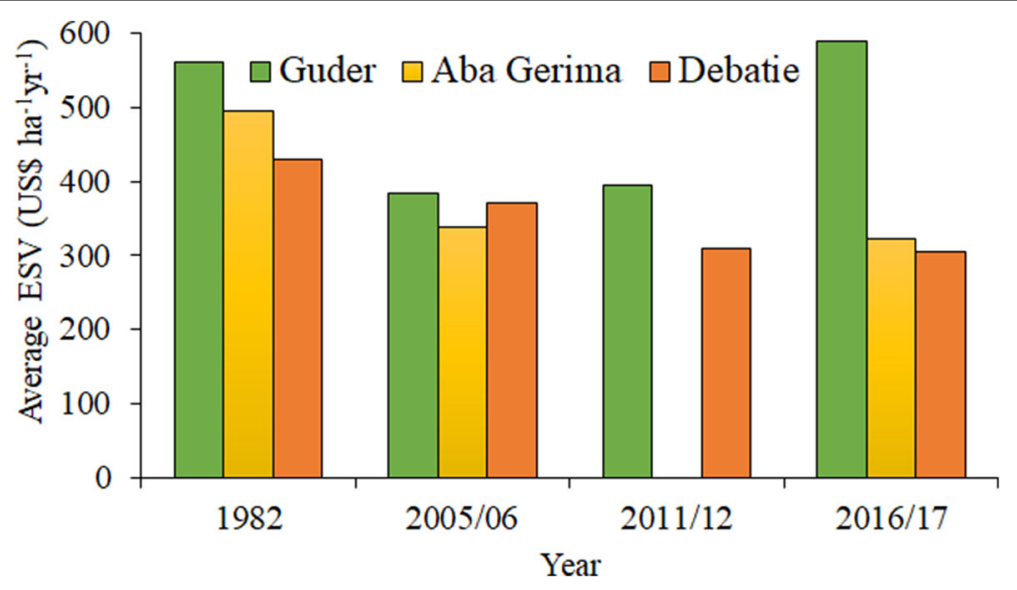

Fig. 3 Average ecosystem service values (ESV) for Guder, Aba Gerima, and Debatie watersheds, Ethiopia, from 1982 to 2016/17 
Table 4 Changes in ecosystem service value (ESV) (US\$, \%) between study years in Guder, Aba Gerima, and Debatie watersheds, Ethiopia. LULC abbreviations as defined in Table TS1

\begin{tabular}{|c|c|c|c|c|c|c|c|c|c|}
\hline \multirow[t]{3}{*}{ Watershed } & \multirow{3}{*}{$\begin{array}{l}\text { LULC } \\
\text { class }^{\text {a }}\end{array}$} & \multicolumn{8}{|c|}{ Change (US\$ [thousands], \%) } \\
\hline & & \multicolumn{2}{|c|}{ 1982-2006 } & \multicolumn{2}{|c|}{ 2006-2012 } & \multicolumn{2}{|c|}{ 2012-2017 } & \multicolumn{2}{|c|}{ 1982-2017 } \\
\hline & & ESV & (\%) & ESV & $(\%)$ & ESV & (\%) & ESV & $(\%)$ \\
\hline \multirow[t]{7}{*}{ Guder } & $\mathrm{BL}$ & -1.4 & -8.5 & -1.8 & -12.4 & -4.8 & -37.0 & -8.0 & -49.5 \\
\hline & $\mathrm{CL}$ & +20.1 & +107.1 & +0.9 & +2.4 & -16.0 & -40.1 & +5.1 & +27.0 \\
\hline & $\mathrm{FL}$ & -92.9 & -67.1 & -1.6 & -3.5 & -2.4 & -5.5 & -96.9 & -70.0 \\
\hline & $\mathrm{GL}$ & -2.1 & -11.0 & -1.3 & -7.5 & -1.8 & -11.7 & -5.2 & -27.3 \\
\hline & $P L$ & +15.6 & - & 7.4 & +47.7 & +91.9 & 399.8 & +114.9 & - \\
\hline & ST & 0.0 & - & 0.0 & - & 0.0 & - & 0.0 & - \\
\hline & Total & -60.6 & & +3.7 & & +66.9 & & +10.0 & \\
\hline \multirow[t]{8}{*}{ Aba Gerima } & LULC & $1982-2$ & & $2005-2$ & & & & $1982-20$ & \\
\hline & $B L$ & -9.9 & -37.4 & -3.0 & -18.0 & - & - & -12.9 & -48.6 \\
\hline & $\mathrm{CL}$ & +26.9 & +122.4 & +1.4 & +2.9 & - & - & +28.3 & +128.9 \\
\hline & $\mathrm{FL}$ & -63.2 & -59.8 & -5.8 & -13.7 & - & - & -69.0 & -65.3 \\
\hline & $\mathrm{GL}$ & -6.9 & -58.9 & -0.5 & -10.9 & - & - & -7.4 & -63.4 \\
\hline & $\mathrm{KC}$ & +0.5 & - & +2.8 & +585.7 & - & - & +3.3 & - \\
\hline & ST & - & - & 0.0 & - & - & - & 0.0 & - \\
\hline & Total & -52.6 & & -5.1 & & - & - & -57.7 & \\
\hline \multirow[t]{7}{*}{ Debatie } & LULC & $1982-2$ & & $2006-2$ & & $2011-2$ & & $1982-20$ & \\
\hline & $B L$ & -9.9 & -37.4 & -4.7 & -28.4 & -1.0 & -8.1 & -15.6 & -58.7 \\
\hline & $\mathrm{CL}$ & +15.7 & +419.7 & +9.1 & +47.0 & +1.5 & +5.3 & +26.3 & 713.5 \\
\hline & $\mathrm{FL}$ & -13.6 & -27.4 & -17.5 & -48.9 & -0.1 & -0.4 & -31.2 & -63.0 \\
\hline & $\mathrm{GL}$ & -6.5 & -24.6 & -2.1 & -10.8 & -1.5 & -8.3 & -10.1 & -38.3 \\
\hline & ST & 0.0 & 0.0 & 0.0 & 0.0 & 0.0 & - & 0.0 & - \\
\hline & Total & -14.3 & & -15.3 & & -1.0 & & -30.5 & \\
\hline
\end{tabular}

of natural vegetation LULC classes such as bush, forest, and grazing lands, agrees well with the findings of previous studies in Ethiopia and elsewhere (e.g., Kindu et al. 2016; Tolessa et al. 2017a, 2017b; Gashaw et al. 2018; Lin et al. 2018; Wang et al. 2018; Yang et al. 2018; Chen et al. 2020).

For example, a previous study conducted in Andassa watershed (Ethiopia) found that the loss of ESV between 1985 and 2015 was mainly due to the loss of natural vegetation such as shrubland and forest (Gashaw et al. 2018).

Similarly, studies by Kindu et al. (2016) in the Munessa-Shashemene landscape of Ethiopia from 1986 to 2012 and Tolessa et al. (2017b) in the Chilimo forest, Ethiopia, from 1973 to 2014 found as in our study that the loss of natural vegetation is the predominant contributor to the reduction in total ESV. Previous studies in China also showed that the reduction of forest substantially reduced the total ESV in the Hengduan Mountain region between 2000 and 2010 (Wang et al. 2018) and in Chengdu City (Lin et al. 2018). Similarly, the expansion of cultivated land resulted in a loss of ESV by
US\$ $11,893.85$ million from 1965 to 2015 in the Small Sanjiang Plain (Chen et al. 2020). In contrast to our findings in Guder watershed, Hu et al. (2008) attributed the extreme loss of ecosystem services in Xishuangbanna to the sudden shift in land use from tropical forests and swidden fields to large rubber plantations from 1988 to 2006.

The average ESVs of the watersheds in our study (US\$ 384-560 $\mathrm{ha}^{-1}$ year $^{-1}$ in Guder watershed, US\$ 323-495 $\mathrm{ha}^{-1}$ year $^{-1}$ in Aba Gerima watershed, and US\$ 306-429 $\mathrm{ha}^{-1}$ year $^{-1}$ in Debatie watershed; Fig. 3) are within the ranges of other estimates for the Ethiopian highlands and similar agro-ecological regions. For example, Gashaw et al. (2018) and Tolessa et al. (2017a) reported average ESVs for Ethiopia ranging from US\$ 358 to US\$ $457 \mathrm{ha}^{-1}$ year $^{-1}$ (1985-2015) and from US\$ 230 to US\$ $467 \mathrm{ha}^{-1}$ year $^{-1}$ (1984-2014), respectively. In contrast, the average ESVs reported for the Munessa-Shashemene landscape of Ethiopia between 1986 and 2012 were greater by far than our estimates, ranging from US\$ 1072 to US\$ $1143 \mathrm{ha}^{-1}$ year $^{-1}$ (Kindu et al. 2016). This difference can be most likely attributed 
Table 5 Effects of land-use/land-cover (LULC) changes on individual ecosystem services from 1982 to 2016/17 in the study watersheds

\begin{tabular}{|c|c|c|c|c|c|c|c|c|c|c|c|}
\hline \multirow[t]{3}{*}{ Ecosystem services } & \multicolumn{11}{|c|}{ ESV (US\$ in thousands) } \\
\hline & \multicolumn{4}{|l|}{ Guder } & \multicolumn{3}{|c|}{ Aba Gerima } & \multicolumn{4}{|c|}{ Debatie } \\
\hline & 1982 & 2006 & 2012 & 2017 & 1982 & 2005 & 2016 & 1982 & 2006 & 2011 & 2017 \\
\hline \multicolumn{12}{|l|}{ Provisioning services } \\
\hline Water supply & 1.1 & 0.5 & 0.5 & 1.3 & 0.9 & 0.3 & 0.3 & 0.4 & 0.3 & 0.1 & 0.1 \\
\hline Food production & 34.2 & 47.1 & 46.8 & 33.7 & 37.0 & 50.7 & 51.4 & 25.9 & 31.9 & 36.2 & 36.5 \\
\hline Raw material & 7.2 & 3.2 & 3.5 & 8.1 & 5.5 & 2.2 & 1.9 & 2.6 & 1.9 & 1.0 & 0.9 \\
\hline Genetic resources & 2.7 & 2.4 & 2.2 & 2.1 & 4.4 & 1.8 & 1.5 & 2.1 & 1.9 & 1.0 & 0.9 \\
\hline Total & 45.2 & 53.1 & 53.0 & 45.2 & 47.7 & 55.1 & 55.2 & 30.9 & 35.9 & 38.3 & 38.5 \\
\hline \multicolumn{12}{|l|}{ Regulating services } \\
\hline Water regulation & 1.2 & 0.7 & 0.7 & 1.2 & 1.0 & 0.5 & 0.4 & 0.8 & 0.6 & 0.4 & 0.4 \\
\hline Water treatment & 29.5 & 17.8 & 17.7 & 28.1 & 25.9 & 12.4 & 11.3 & 22.5 & 15.8 & 11.3 & 10.6 \\
\hline Erosion control & 37.9 & 18.3 & 19.5 & 41.0 & 30.0 & 12.7 & 11.2 & 17.5 & 12.5 & 7.5 & 7.2 \\
\hline Climate regulation & 31.3 & 13.8 & 15.1 & 35.4 & 23.9 & 9.6 & 8.3 & 11.2 & 8.1 & 4.1 & 4.1 \\
\hline Biological control & 4.8 & 6.6 & 6.5 & 4.3 & 5.3 & 6.9 & 7.0 & 4.5 & 4.9 & 5.4 & 5.3 \\
\hline Gas regulation & 2.8 & 1.6 & 1.6 & 2.7 & 2.4 & 1.1 & 1.0 & 1.9 & 1.4 & 1.0 & 0.9 \\
\hline Disturbance regulation & 0.7 & 0.3 & 0.3 & 0.8 & 0.5 & 0.2 & 0.2 & 0.3 & 0.2 & 0.1 & 0.1 \\
\hline Total & 108.1 & 59.2 & 61.5 & 113.4 & 89.1 & 43.4 & 39.5 & 58.8 & 43.5 & 29.8 & 28.7 \\
\hline \multicolumn{12}{|l|}{ Supporting services } \\
\hline Nutrient cycling & 25.9 & 11.4 & 12.5 & 29.2 & 19.7 & 7.9 & 6.9 & 9.2 & 6.7 & 3.4 & 3.4 \\
\hline Pollination & 5.2 & 5.6 & 5.4 & 4.5 & 5.4 & 5.2 & 5.2 & 5.1 & 4.6 & 4.4 & 4.3 \\
\hline Soil formation & 1.5 & 0.7 & 0.8 & 1.7 & 1.2 & 0.5 & 0.4 & 0.7 & 0.5 & 0.3 & 0.3 \\
\hline Habitat/refugia & 2.4 & 1.1 & 1.2 & 2.7 & 1.9 & 0.7 & 0.6 & 0.9 & 0.6 & 0.3 & 0.3 \\
\hline Total & 35.0 & 18.8 & 19.9 & 38.2 & 28.2 & 14.4 & 13.1 & 15.9 & 12.4 & 8.5 & 8.3 \\
\hline \multicolumn{12}{|l|}{ Cultural services } \\
\hline Recreation & 0.8 & 0.4 & 0.4 & 0.8 & 0.6 & 0.3 & 0.2 & 0.4 & 0.3 & 0.2 & 0.2 \\
\hline Cultural & 0.3 & 0.1 & 0.1 & 0.3 & 0.2 & 0.1 & 0.1 & 0.1 & 0.3 & 0.2 & 0.2 \\
\hline Total & 1.1 & 0.5 & 0.5 & 1.1 & 0.8 & 0.4 & 0.3 & 0.5 & 0.5 & 0.3 & 0.3 \\
\hline
\end{tabular}

to the dominance of cultivated land in our study watersheds over the study period except in 1982 (in all watersheds) and after 2012 (only in Guder watershed; Table TS3). Also, our estimates of average ESVs are lower than those of Tolessa et al. (2017b) for Ethiopia, and Wang et al. (2015) for China. This might be attributable to differences in the ecosystem service coefficients used; we used modified ecosystem service coefficients applied to Ethiopian conditions (Kindu et al. 2016), whereas Tolessa et al. (2017b) and Wang et al. (2015) used coefficients developed by Costanza et al. (1997).

\section{Changes in specific ESVs}

The major contributors to ecosystem services in Guder watershed were regulating services (mainly as water treatment and erosion control), followed by provisioning services. Regulating service contributions ranged from a low level of $45.0 \%$ (US\$ 59.2 thousand) in 2006 to a high level of 57.3\% (US\$ 113.4 thousand) in 2017 (Table 5). As in Guder watershed, regulating services were the major contributor to the total ESV in Aba Gerima watershed in 1982, at about 54\% (US\$ 89.1 thousand; Table 5). In 2005 and 2016, however, provisioning services became the highest contributor to total ESV, at about $49 \%$ (US\$ 55.1 thousand) and 51\% (US\$ 55.2 thousand), respectively (Table 5). As in Aba Gerima watershed, the major contributors to the total ESV in Debatie watershed were provisioning and regulating services. Provisioning services predominated in 1982 (about 55\%; US\$ 59 thousand) and in 2006 (47\%; US\$ 44 thousand), whereas regulating services were predominant in 2011 (50\%; US\$ 38 thousand) and in 2017 (51\%; US\$ 39 thousand; Table 5). In general, in the three watersheds, more than $70 \%$ of total ESV came from the provisioning services (mainly as food production) and regulating services (mainly as water treatment, erosion control, and 
climate regulation; Table 5). In contrast, cultural services accounted for the smallest percentage of total ecosystem services in all study watersheds over the study period (Table 5). This might be due to the assigned small ESV coefficient values in cultural services for each LULC class compared with other ecosystem services. In general, the results presented in Table 5 show that there are different effects of LULC changes on individual ecosystem services; the changes increased the value of some ecosystem services, while others were reduced.

Our findings support previous studies in Ethiopia that showed that provisioning and regulating services are the major contributors to the total changes in ESV in Andassa watershed (Ethiopia) from 1985 to 2015 (Gashaw et al. 2018). Correspondingly, a decrease in natural vegetation (bush, forest, and grazing lands) in the Munessa-Shashemene landscape (Kindu et al. 2016) and Chilimo forest (Tolessa et al. 2017b) of Ethiopia has resulted in the reduction of several ecosystem functions and the increase of food production services. Elsewhere, decreases in grasslands, forest, woodlands, and aquatic regions between 1980 and 2005 in Small Sanjiang Plain (Chen et al. 2020), Nenjiang River basin (Wang et al. 2015), and Manas River basin (Wang et al. 2017), China, resulted in a decrease in the value of ecosystem services such as climate regulation, gas regulation, and a variety of other types of ecosystem services. It is worth mentioning, therefore, that LULC changes in the study watersheds, mainly in the form of expansion of cultivated land, resulted in a marked loss of total and specific ESVs, whereas plantations show high potential for restoring the ESVs (Tables 4 and 5). Thus, as in Guder (highland) watershed, changing cultivated land to plantations through an integrated watershed approach would improve the land cover, thereby enhancing ecosystem services.

\section{Variation of ESV in response to population growth and farming practices}

We investigated the relationship between changes in total ESV and population number for the years 1982, 1994, 2007, and 2016 (Fig. 4). There was an increasing population trend at the Guder site throughout the entire study period (1982-2016; Fig. 4). The increase was consistent and had an inverse relationship with the total and specific ESVs (regulating, supporting, and cultural services) between 1982 and 2006; it was positively correlated with provisioning services while these relationships were reversed after 2006 (Figs. 4 and 5). This change was mainly due to the increase of vegetation cover at the expense of cultivated land (Fig. 5), resulting primarily from farmers' growing interest in allocating more area to plantations (mainly as $A$. decurrens) to overcome a decline in soil fertility and to grow $A$. decurrens for income generation activity (Belete 2015; Wondie and Mekuria 2018).

In contrast to the other two watersheds, the change in population number in Aba Gerima was more consistent between the consecutive study periods. Between 1982 and 2005, the reduction of ESV was strongly linked with the increase in population numbers (Fig. 4). However, even though the population number increased after 2007, the ESV did not substantially change (Table 4, Fig. 4). This is mainly attributable to less expansion of cultivated land and a slight increase in vegetation cover as khat cultivation (Table TS2), due to the farmers' interest in increasing farm diversification and having an alternate source of income ( Belete 2015; Abeje et al. 2019).

In Debatie watershed, the population number increased throughout the entire study period (1982-2017), particularly after 1994. This increase is mainly attribute to the implementation of a resettlement policy in the Debatie districts in the mid-1980s (Woldemeskel 1989). This policy resulted in a substantial expansion of cultivated land and a decline in natural vegetation cover (mainly as bushland and grazing land; Table TS3, S4) due to deforestation to meet the increasing demand for agricultural production and firewood (Berihun et al. 2019a). Thus, the population increase was negatively associated with total and specific ESVs while positively associated with the expansion of cultivated land at the expense of vegetation cover over the study periods (Figs. 5 and 6).

In general, population growth along with changes in LULC appear to be the main factors behind ESV changes in the study watersheds, which were largely articulated through the expansion of cultivated lands at the expense of natural vegetation cover, particularly in Aba Gerima and Debatie watersheds (Fig. 5). Previous studies elsewhere had similar findings, recognizing socio-economic factors such as population growth as important elements that directly or indirectly affect ecosystem services as a result of the enormous pressure on ecosystems (e.g., Wu et al. 2013; Hou et al. 2014; Wang et al. 2015; Cheng et al. 2018; Wang et al. 2018; Liu et al. 2019). Thus, the expansion of cultivated land, charcoal production, and harvesting of fuelwood and other wood products, such as those for house construction, associated with increasing population were the major proximate drivers behind the loss of total ESV in the study watersheds.

On the other hand, changing farming practices in Guder and Aba Gerima watersheds are the main causes of the changes in ESVs resulting from the increase in vegetation cover (mainly due to plantation) at the expense of cultivated land (Figs. 3 and 6). For example, after 2006, a major shift from traditional annual 

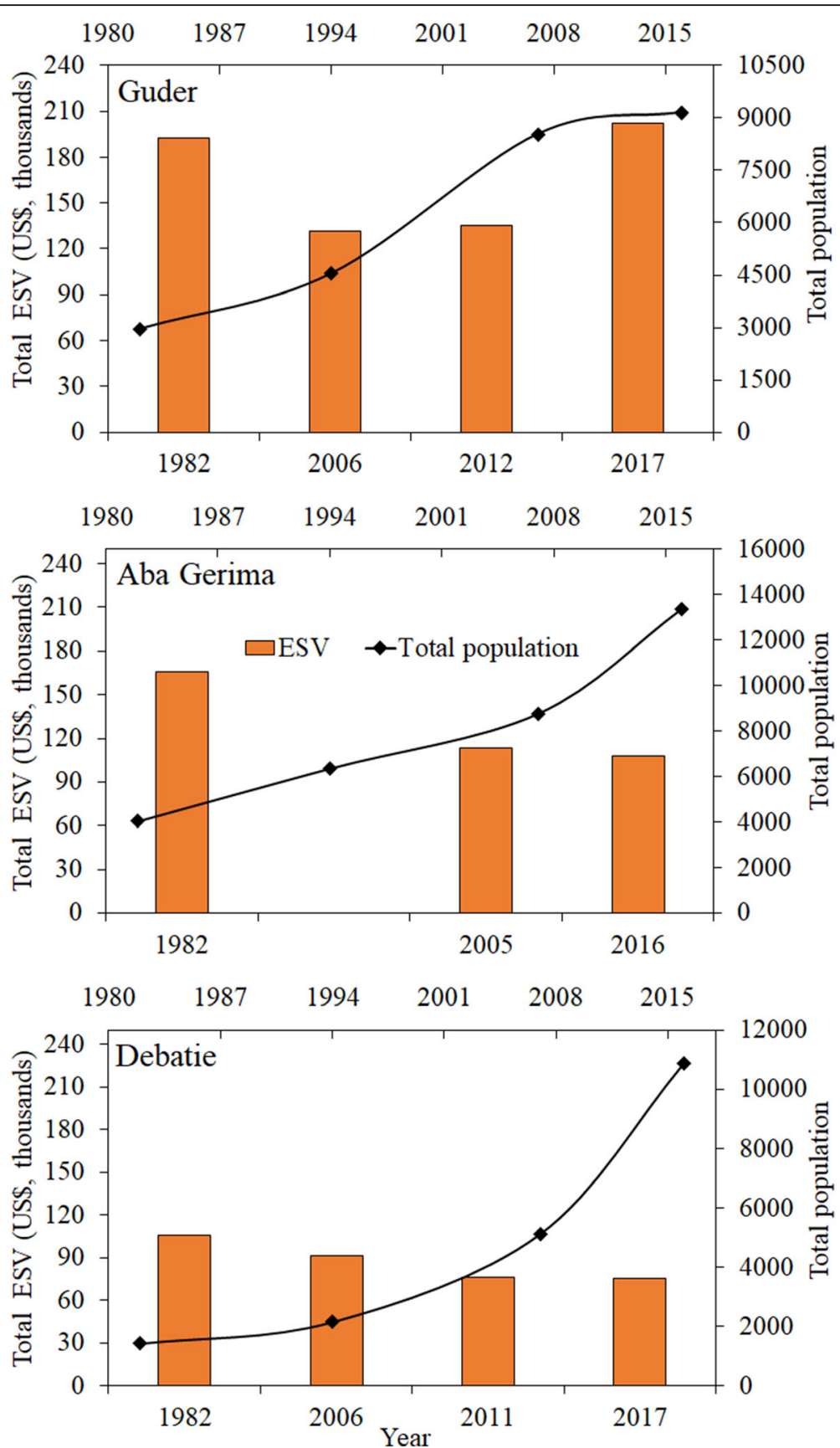

Fig. 4 Relationship between total ecosystem service value (ESV) and population size from 1982 to 2017 in Guder, Aba Gerima, and Debatie watersheds, Ethiopia

cropping system to more economically attractive treebased farming practices, such as $A$. decurrens plantations in Guder (Fig. 6) and khat cultivation in Aba Gerima is more obvious (Table TS3). In Guder watershed in particular, the total ESV increased by US\$ 70.6 thousand after 2006 (Table 4). Local communities use such practices as alternative sources of income as well as to improve environmental conditions by converting degraded cultivated land to plantations, predominantly with nitrogen-fixing $A$. decurrens trees (Belete 2015; Wondie and Mekuria 2018; Abeje et al. 2019). Similarly, previous studies reported that high economic return and good market opportunities resulted in the expansion of khat cultivation in Aba Gerima watershed (Belete 2015; Abeje et al. 2019).

Our LULC change and conversions of LULC classes also show that there is prominent landscape rehabilitation (restoration of vegetation cover) in the highland 

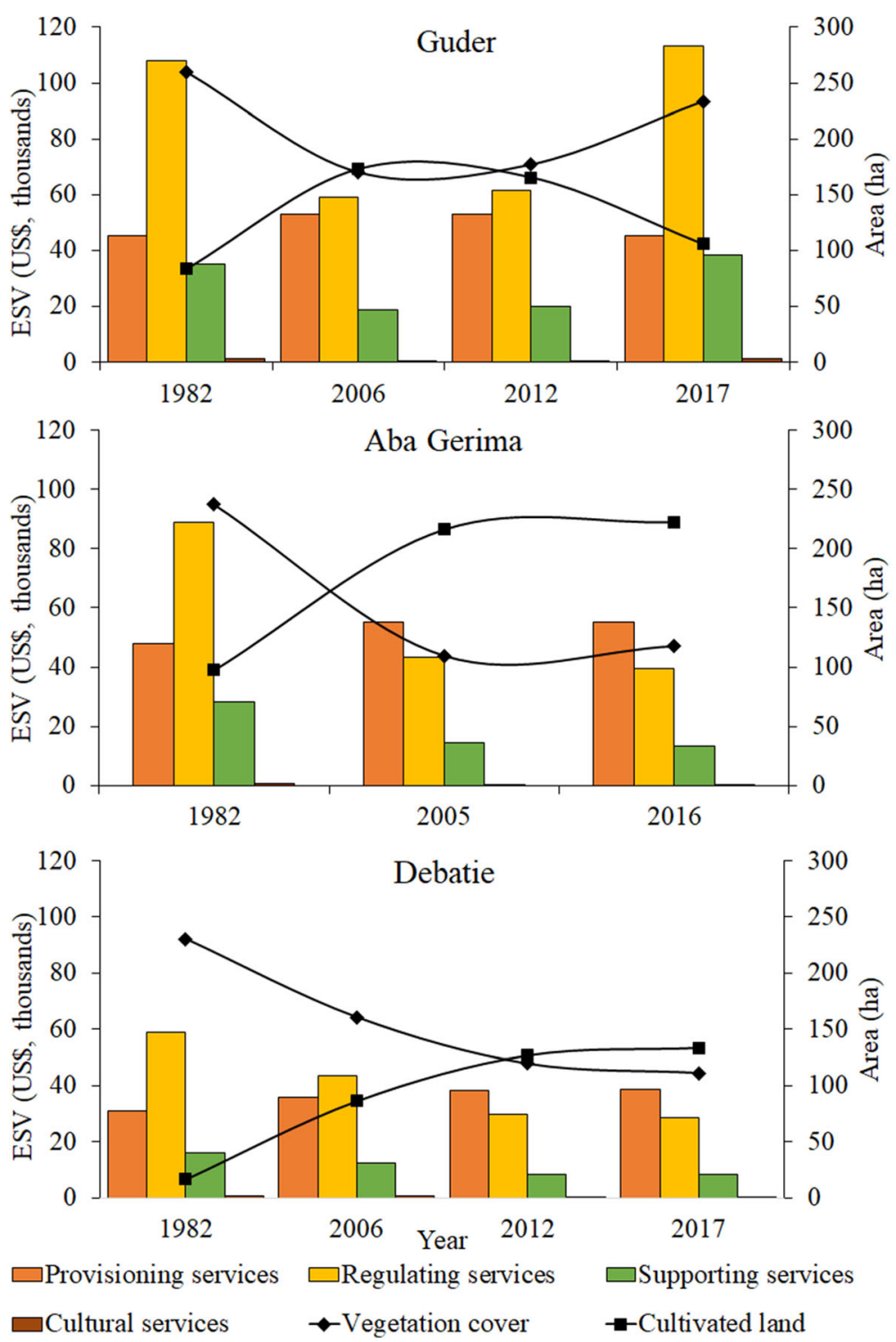

Fig. 5 Changes in four main ecosystem services values (ESVs) along with the area of vegetation cover and cultivated land from 1982 to 2017 in Guder, Aba Gerima, and Debatie watersheds, Ethiopia

(Guder) areas due to the unprecedented expansion of $A$. decurrens plantations since 2006 and the associated recovery of the watershed ESV (Table TS3). In contrast, lowland (Debatie) areas have apparently experienced landscape degradation (loss of vegetation cover) accompanied by a steady decline in ESV as a result of the extreme expansion of cultivated land at the expense of natural vegetation cover (Figs. 2 and 5). Even though the condition of the landscape in the midland (Aba Gerima) areas falls between those of the highland and lowland (Figs. 4 and 5), the loss of total ESV was higher than that in Debatie watershed. Therefore, the experience gained from landscape rehabilitation in the highland areas could be adopted in the midland and lowland watersheds to recover their lost ESVs. Moreover, for all watersheds, 2005/06 was a turning point: after continued losses over 1982-2005/06, total ESVs either became almost stable, as in Aba Gerima and Debatie, or improved, as in Guder (Figs. 4 and 5). The stabilizations resulted from halting the decrease in natural vegetation cover (Figs. 4 and 5).

\section{Future measures and directions to restore ESVs in the} study areas and beyond

In the Ethiopian highlands, social, economic, and policy factors along with population growth have resulted in a substantial expansion of the area of cultivated land at the expense of natural vegetation. Human activities in particular have significantly changed the status of LULC 

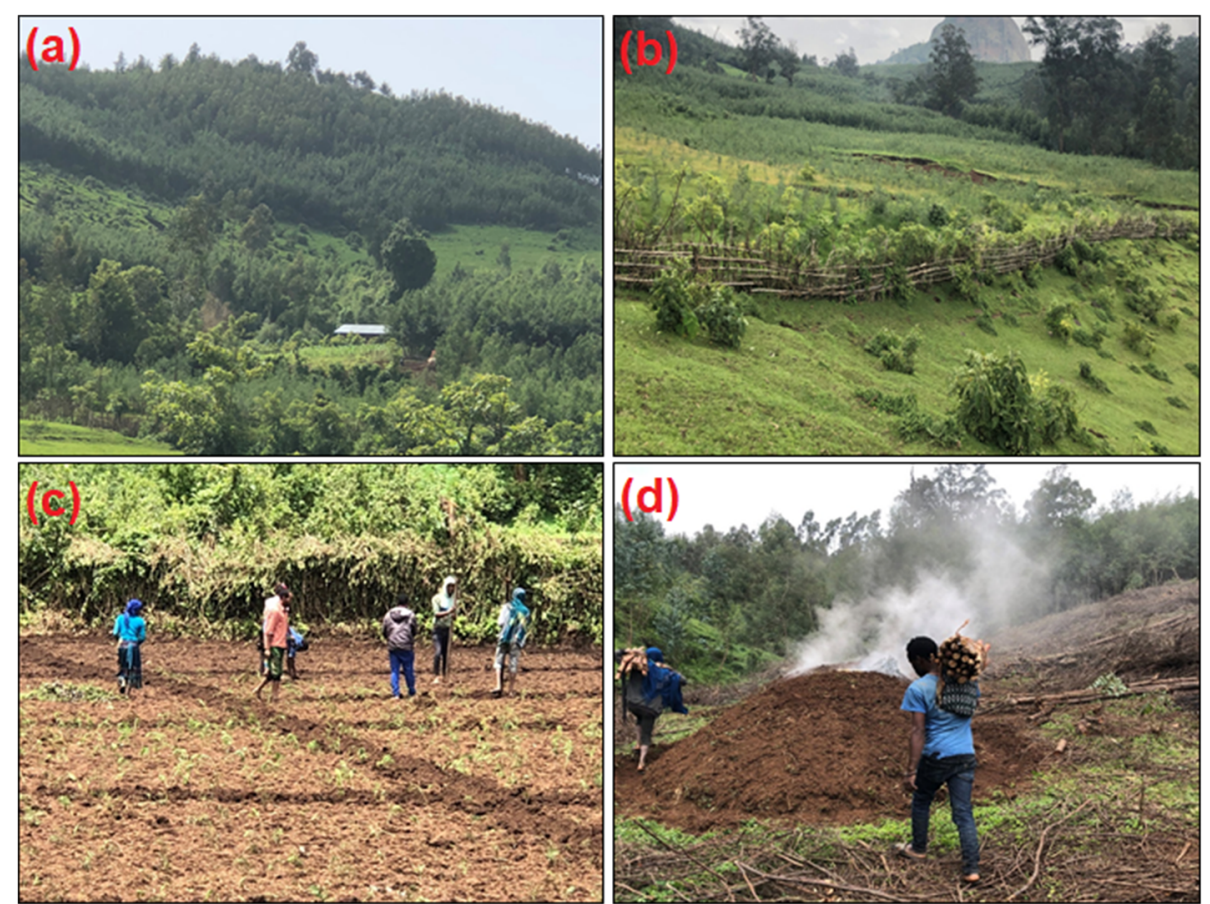

Fig. $\mathbf{6}$ a Example of an Acacia decurrens plantation, $\mathbf{b}$ a plantation on grazing land, $\mathbf{c}$ planting on cultivated land, and $\mathbf{d}$ the traditional process of producing fuel wood (charcoal) from A. decurrens trees in Guder watershed, Ethiopia

in the Upper Blue Nile basin (Gebrehiwot et al. 2014; Berihun et al. 2019a) and subsequently resulted in the loss of the ecosystem services of the area (e.g., Tolessa et al. 2017a; Gashaw et al. 2018). Over time, these losses will lead to an increasingly fragile and unstable naturesociety-economy system in the area, and human beings will bear the consequences ( Wang et al. 2017; Mamat et al. 2018).

Similarly, the decrease in ESV in the study watersheds was mainly caused by rapid changes in LULC along with various human activities; this can limit the capacity of ecosystem service functions, probably resulting in the long-term environmental quality degradation. Considering the fragile natural environment of the study area, we suggest that human activities in the study watersheds, and in the Upper Blue Nile basin, should be pursued with caution, as anthropogenic activities here will have an irreversible impact on ecosystem services. This should be considered in developing future measures and directions, particularly for the watersheds in the midland and lowland agro-ecological environments of the Upper Blue Nile basin. As this study has shown, forest and plantations provide higher ESVs than other LULC classes in the three study watersheds; hence, a reduction in these particular components of the ecosystem hampers a balanced flow of services. Importantly, to recover the ecosystem services in the midland and lowland areas, woodlot agroforestry, such as plantation farming, should be adpted in the Aba Gerima and Debatie areas using the knowledge and experience gained from the Guder plantations (Fig. 6).

In Guder watershed, farmers created extensive $A$. decurrens plantations (a new, economically competitive farm activity) for income generation, charcoal production, and fuelwood activities (Belete 2015; Fig. 6d). The expansion of $A$. decurrens plantations resulted in a large land area being withdrawn from cultivation and grazing lands (Fig. 6b, c), particularly after 2006. This increased the vegetation cover of the watershed by $34 \%$ in 2014 , by which time $50 \%$ of cultivated lands had been converted to A. decurrens woodlots (Belete 2015; Wondie and Mekuria 2018; Berihun et al. 2019a). Incorporating such plantation activities at the watershed scale, along with a conservation strategy, could improve the vegetation cover in the midland and lowland areas. These activities will also help local communities generate income from the watershed and thereby maintain the ESV. Caution must be taken, however, when implementing plantation activities because the value of plantations for biodiversity varies depending on the species type, and the value of the original land cover must be considered (Bremer and Farley 2010; Taki et al. 2011; Onyekwelu and Olabiwonnu 2016; Ulya et al. 2019). Particularly, plantation of non-native tree species could have a strong negative impact on ecosystem services when they naturalize and subsequently become invasive and disrupt or transform communities and 
ecosystems (Dickie et al. 2014). Likewise, Acacia decurrens plantations have a wide range of impacts on ecosystems that increase with time, alter and reduce ecosystem service delivery (Le Maitre et al. 2011; Dickie et al. 2014; Milanović et al. 2020). Thus, active intervention and restoration of native species crucial to recover the pre-invasion condition of the environment is of paramount importance. On the other hand, plantations can contribute positively to the ecosystem services and biodiversity when planted on degraded lands rather than replacing non-native or natural ecosystems (Ulya et al. 2019; Bremer and Farley 2010).

In support of these changes, policymakers should implement a reasonable land-use policy that protects natural vegetation such as forest, bushland, and grass land, which have high ESVs compared to other LULC classes. Local farmers and communities should protect the ecosystem and understand the importance of ecosystem services to maintain a balance between economic development and ecosystem health in the future.

Moreover, quantitative evaluation of changes in ESVs at the watershed scale as well as the basin scale can easily create a common understanding of the ongoing LULC dynamics and indicate the vulnerability of each ecosystem service (Costanza et al. 1997; Cheng et al. 2018; Lin et al. 2018; Negash et al. 2020). Furthermore, such an evaluation can also provide insight for decisionmaking processes and help to develop a land-use planning framework vital for maintaining the sustainability of natural resources (Costanza et al. 1997; de Groot et al. 2012; Chen et al. 2020).

\section{Limitations of this study}

This study used the modified ESV coefficients (Kindu et al. 2016) by employing the value transfer method to estimate the impact of LULC change on ESVs. These estimations have uncertainties and limitations for the following reasons. First, this study assumes homogeneity of the ESVs and no change within each LULC class (Kindu et al. 2016; Lin et al. 2018). However, the variation and complexity of human activity and environmental systems can cause expected errors by value generalization and transfer. For example, as a result of their small areal extent compared with other LULC classes, eucalyptus and riverine trees are categorized in the natural forest LULC class in Aba Gerima and Debatie watersheds, whereas eucalyptus trees are categorized as plantation LULC class in Guder watershed (Table TS2). Also, both natural forest and plantation land in the study area were grouped in the tropical forest biome, whereas they have different influences on biodiversity (e.g., Putz and Redford 2010; Taki et al. 2011; Ulya et al. 2019). Second, even though we classified the LULC of the study areas using an integrating, screen-digitizing technique and very high-resolution satellite images, there is some uncertainty associated with the accuracy of LULC classification (Berihun et al. 2019a). Third, although plantation and natural forest have different responses in some economic values of biodiversity (e.g., Bremer and Farley 2010; Putz and Redford 2010; Taki et al. 2011; Liu et al. 2019; Ulya et al. 2019), we assumed similar ESV coefficients for both LULC classes, as in previous studies in Ethiopia and elsewhere (e.g., Kindu et al. 2016; Tolessa et al. 2017b; Tolessa et al. 2017a; Gashaw et al. 2018; Lin et al. 2018; Wang et al. 2018; Yang et al. 2018; Chen et al. 2020). For example, previous studies in Guder watershed showed that the responses of various ecosystem services such as forage biomass production, soil properties improvement, runoff, and gully erosion control to noticeably higher in natural forest than $A$. decurrens plantations (Berihun et al. 2019b; Yibeltal et al. 2019a, 2019b; Abebe et al. 2020). However, the value or the impact of this plantations for biodiversity and ecosystem services varies with the species type and can vary on the basis of whether the original land cover was native or exotic tree species are planted (Bremer and Farley 2010; Paquette and Messier 2010; Onyekwelu and Olabiwonnu 2016; Ulya et al. 2019). When established on degraded lands rather than replacing natural ecosystems, plantations positively to contribute to biodiversity (Bremer and Farley 2010; Ulya et al. 2019). In this study, therefore, plantations positively supported the biodiversity values of the watershed because plantation activities (particularly in Guder watershed) were conducted on areas degraded by cultivated land (Fig. 6b, c; Berihun et al. 2019a). It is possible that the values of the plantation ecosystem services in Guder watershed were overestimated because they were assigned ESV coefficients similar to natural forest. Fourth, khat cultivation was introduced in the Aba Gerima watershed during 2005 (Berihun et al. 2019a) and currently a common practice at this watershed for both socio-economic and agroecological reasons (Birhane 2014; Abeje et al. 2019). Unlike bushland, this perennial crop (khat) needs a supply of water by irrigation at the early stage and then it becomes evergreen shrub (Birhane 2014; Kandari et al. 2014). Despite such difference, the same ESV coefficient was assigned for both LULC classes (Khat and bushland) since khat cultivation has been categorized under a large shrub family (Kandari et al. 2014).

Moreover, as described in previous studies (e.g., Wang et al. 2015; Tolessa et al. 2017b; Mamat et al. 2018; Wang et al. 2018; Negash et al. 2020), sensitivity coefficients can be calculated to validate the reliability of study results, and in these studies the value coefficients of ESVs were adjusted by $50 \%$ in most cases. However, we did not apply this method for the reasons briefly described in previous studies (e.g., Gashaw et al. 2018; Lin 
et al. 2018). The use of the sensitivity coefficients method to test the constancy of evaluation results was criticized by Aschonitis et al. (2016), because the value of sensitivity coefficients is often less than one even when value coefficients were adjusted by $25 \%$, which indicates that the coefficients are erroneously robust. Therefore, we did not employ the sensitivity coefficients analysis method.

\section{Conclusions}

We evaluated the impact of LULC changes on ESVs from 1982 to 2016/17 by employing modified ESV coefficients and the value transfer method in contrasting agro-ecological environments: Guder (highland), Aba Gerima (midland), and Debatie (lowland) watersheds of the Upper Blue Nile basin. Our results reveal that the expansion of cultivated land at the expense of natural vegetation (bushland, forest, and grazing land) clearly reduced the total and individual ecosystem services ranging from US\$ 58 thousand (35\%) in Aba Gerima to US\$ 31 thousand (29\%) in Debatie watershed between 1982 to 2016/17. In contrast, the unprecedented expansion of plantations mainly as $A$. decurrens, resulted in a recovery of total ESV by US\$ 71 thousand (54\%) in Guder watershed after 2006, following a decrease of about US\$ 61 thousand (32\%) between 1982 and 2006. Importantly, the loss of forested land and the expansion of cultivated land were the major contributors to the reduction of ESV in Aba Gerima and Debatie as well as in Guder watershed from 1982 to 2006. Specific ecosystem services, such as provisioning (mainly as food production) and regulating services (mainly as erosion control and climate regulation) accounted for most of the total ESVs in the study watersheds. The total and specific ESVs were negatively associated with population growth and the expansion of cultivated land at the expense of vegetation cover over the study period. However, a positive association between population growth and ESV in Guder watershed during 2012-2017 mainly resulted from changes in farming practices because of the farmers' growing interest in allocating more land to plantations (predominantly $A$. decurrens) to remedy a decline in soil fertility and for income generation activities such as firewood and charcoal production. Therefore, future measures and directions should focus on improving vegetation cover through plantation activities, as in Guder watershed, to avoid the expected loss of ESV due to expansion of cultivated land evident in the midland and lowland watersheds.

\section{Abbreviations}

CSA: Central Statistical Authority; ESV: Ecosystem service value; ESV: Ecosystem service value functions; LULC: Land use/land cover; SRTMDEM: Shuttle Radar Topography Mission Digital Elevation Model

\section{Supplementary Information}

The online version contains supplementary material available at https://doi. org/10.1186/s13717-021-00325-1.

Additional file 1: Table TS1, Table S2, Table TS3, Table S4, Table S5, Table S6 and Fig. FS1

\section{Acknowledgement}

This research was funded by the Science and Technology Research Partnership for Sustainable Development (SATREPS, grant number JPMJSA 1601), Japan Science and Technology Agency (JST) / Japan International Cooperation Agency (JICA). We thank all the research assistants for providing field support. We also thank the Arid Land Research Centre, Tottori University, for providing an appropriate research environment

\section{Authors' contributions}

MLB: conceptualization, methodology, software, formal analysis, investigation, resources, data curation, writing-original draft, writing-review and editing, visualization. AT, NH, and MT: resources, writing-review and editing, visualization, supervision, project administration, funding acquisition. AAF: methodology, investigation, writing-review and editing, visualization. The author(s) read and approved the final manuscript.

\section{Funding}

The study is funded by Science and Technology Research Partnership for Sustainable Development (SATREPS, grant number JPMJSA1601), Japan Science and Technology Agency (JST) / Japan International Cooperation Agency (JICA)

\section{Availability of data and materials}

The datasets used and/or analyzed during the current study are available from the corresponding author on reasonable request.

\section{Declarations}

Ethics approval and consent to participate

Not applicable.

Consent for publication

All authors agreed and approved the manuscript for publication in Ecological Processes.

Competing interests

The authors declare that they have no competing interest.

\section{Author details}

${ }^{1}$ Faculty of Civil and Water Resources Engineering, Bahir Dar Institute of Technology, Bahir Dar University, P.O. Box 26, Bahir Dar, Ethiopia. ${ }^{2}$ Arid Land Research Center, Tottori University, 1390 Hamasaka, Tottori 680-0001, Japan. ${ }^{3}$ International Platform for Dryland Research and Education, Tottori University, 1390 Hamasaka, Tottori 680-0001, Japan.

Received: 10 October 2020 Accepted: 1 July 2021

Published online: 22 July 2021

\section{References}

[CSA] Central Statistical Authority (1994) Fedral Democratic Republic of Ethiopia Office of Population and Housing Census Commission Centeral Statistical Authority the 1994 Population and Housing Census of Ethiopia Result Analytical Report

[CSA] Central Statistical Authority (2007) Fedral Democratic Republic of Ethiopia Office of Population and Housing Census Commission Centeral Statistical Authority the 2007 Population and Housing Census of Ethiopia Result Analytical Report.

[MEA] Millennium Ecosystem Assessment (2005) Ecosystems and human wellbeing: synthesis. Island Press, Washington, DC

Abebe G, Tsunekawa A, Haregeweyn N, Takeshi T, Wondie M, Adgo E, Masunaga T, Tsubo M, Ebabu K, Berihun ML, Tassew A (2020) Effects of land use and topographic position on soil organic carbon and total nitrogen stocks in 
different agro-ecosystems of the Upper Blue Nile basin. Sustainability 12(6): 2425. https://doi.org/10.3390/su12062425

Abeje MT, Tsunekawa A, Haregeweyn N, Nigussie Z, Adgo E, Ayalew Z, Tsubo M, Elias A, Berihun D, Quandt A, Berihun ML, Masunaga T (2019) Communities' livelihood vulnerability to climate variability in Ethiopia. Sustainability 11(22): 6302. https://doi.org/10.3390/su11226302

Aschonitis VG, Gaglio M, Castaldelli G, Fano EA (2016) Criticism on elasticitysensitivity coefficient for assessing the robustness and sensitivity of ecosystem services values. Ecosyst Serv 20:66-68. https://doi.org/10.1016/j. ecoser.2016.07.004

Belete AK (2015) Integration of Acacia decurrens (J.C. Wendl.) Willd. into the farming system, its effects on soil fertility and comparative economic advantages in north-western Ethiopia. MSc Thesis. Bahir Dar Univ., Ethiopia

Berihun ML, Tsunekawa A, Haregeweyn N, Dile YT, Tsubo M, Fenta AA, Meshesha DT, Ebabu K, Sultan D, Srinivasan R (2020) Evaluating runoff and sediment responses to soil and water conservation practices by employing alternative modeling approaches. Sci Total Environ 747:141118. https://doi.org/10.1016/j. scitotenv.2020.141118

Berihun ML, Tsunekawa A, Haregeweyn N, Meshesha DT, Adgo E, Tsubo M, Masunaga T, Fenta AA, Sultan D, Yibeltal M (2019a) Exploring land use/land cover changes, drivers and their implications in contrasting agro-ecological environments of Ethiopia. Land Use Policy 87:104052. https://doi.org/10.101 6/j.landusepol.2019.104052

Berihun ML, Tsunekawa A, Haregeweyn N, Meshesha DT, Adgo E, Tsubo M, Masunaga T, Fenta AA, Sultan D, Yibeltal M, Ebabu K (2019b) Hydrological responses to land use/land cover change and climate variability in contrasting agro-ecological environments of the Upper Blue Nile basin, Ethiopia. Sci Total Environ 689:347-365. https://doi.org/10.1016/j.scitotenv.201 9.06 .338

Birhane BW (2014) The effect of Khat (Catha edulis) chewing on blood pressure among male adult chewers, Bahir Dar, North West Ethiopia. Sci J Public Heal 2(5):461-468. https://doi.org/10.11648/j.sjph.20140205.23

Bremer LL, Farley KA (2010) Does plantation forestry restore biodiversity or create green deserts? A synthesis of the effects of land-use transitions on plant species richness. Biodivers Conserv 19(14):3893-3915. https://doi.org/10.1007/ s10531-010-9936-4

Chen J, Yu L, Yan F, Zhang S (2020) Ecosystem service loss in response to agricultural expansion in the small Sanjiang Plain, Northeast China: process, driver and management. Sustainability 12(6):2430. https://doi.org/10.3390/ su12062430

Cheng X, Chen L, Sun R, Kong P (2018) Land use changes and socio-economic development strongly deteriorate river ecosystem health in one of the largest basins in China. Sci Total Environ 616:376-385

Costanza R, D'Arge R, De Groot R, Farber S, Grasso M, Hannon B, Limburg K, Naeem S, O'Neill RV, Paruelo J, Raskin RG, Sutton P, Van Den Belt M (1997) The value of the world's ecosystem services and natural capital. Nature 387(6630):253-260. https://doi.org/10.1038/387253a0

Costanza R, de Groot R, Sutton P, van der Ploeg S, Anderson SJ, Kubiszewski I, Farber S, Turner RK (2014) Changes in the global value of ecosystem services. Glob Environ Chang 26:152-158. https://doi.org/10.1016/j.gloenvcha.2014.04. 002

de Groot R, Brander L, van der Ploeg S, Costanza R, Bernard F, Braat L, Christie M, Crossman N, Ghermandi A, Hein L, Hussain S, Kumar P, McVittie A, Portela R, Rodriguez LC, ten Brink P, van Beukering P (2012) Global estimates of the value of ecosystems and their services in monetary units. Ecosyst Serv 1(1): 50-61. https://doi.org/10.1016/j.ecoser.2012.07.005

Dickie IA, Bennett BM, Burrows LE, Nunez MA, Peltzer DA, Porté A, Van Wilgen BW (2014) Conflicting values: ecosystem services and invasive tree management. Biol Invasions 16(3):705-719. https://doi.org/10.1007/s10530013-0609-6

Fenta AA, Tsunekawa A, Haregeweyn N, Tsubo M, Yasuda H, Kawai T, Ebabu K, Berihun ML, Belay AS, Sultan D (2021) Agroecology-based soil erosion assessment for better conservation planning in Ethiopian river basins. Environ Res 195:110786. https://doi.org/10.1016/j.envres.2021.110786

Fenta AA, Tsunekawa A, Haregeweyn N, Tsubo M, Yasuda H, Shimizu K, Kawai T, Ebabu K, Berihun ML, Sultan D, Belay AS (2020) Cropland expansion outweighs the monetary effect of declining natural vegetation on ecosystem services in sub-Saharan Africa. Ecosyst Serv 45:101154. https://doi.org/10.101 6/j.ecoser.2020.101154

Fenta AA, Yasuda H, Shimizu K, Haregeweyn N (2017) Response of streamflow to climate variability and changes in human activities in the semiarid highlands of northern Ethiopia. Reg Environ Chang 17(4):1229-1240. https://doi.org/1 0.1007/s10113-017-1103-y

Fenta AA, Yasuda H, Shimizu K, Haregeweyn N, Negussie A (2016) Dynamics of soil erosion as influenced by watershed management practices: a case study of the Agula watershed in the semi-arid highlands ofnorthern Ethiopia. Environ Manag 58(5):889-905. https://doi.org/10.1007/s00267-016-0757-4

Gashaw T, Tulu T, Argaw M, Worqlul AW, Tolessa T, Kindu M (2018) Estimating the impacts of land use/land cover changes on ecosystem service values: the case of the Andassa watershed in the Upper Blue Nile basin of Ethiopia. Ecosyst Serv 31:219-228. https://doi.org/10.1016/j.ecoser.2018.05.001

Gebrehiwot SG, Bewket W, Gärdenäs Al, Bishop K (2014) Forest cover change over four decades in the Blue Nile basin, Ethiopia: comparison of three watersheds. Reg Environ Chang 14:253-266

Goldewijk K, Ramankutty N (2004) Land cover change over the last three centuries due to human activities: The availability of new global data sets. GeoJournal 61(4):335-344. https://doi.org/10.1007/s10708-004-5050-z

Haregeweyn N, Tsunekawa A, Tsubo M, Fenta AA, Gelaw KE, Kebede B, Berihun ML, Yibeltal M (2019) Overview of global SLM: a review on its distribution, successes and failures and its implications towards achieving a LDN world. In: AGU Fall Meeting 2019. AGU

Haregeweyn N, Tsunekawa A, Tsubo M, Meshesha D, Adgo E, Poesen J, Schütt B (2016) Analyzing the hydrologic effects of region-wide land and water development interventions: a case study of the Upper Blue Nile basin. Reg Environ Chang 16(4):951-966. https://doi.org/10.1007/s10113-015-0813-2

Hou Y, Zhou S, Burkhard B, Müller F (2014) Socioeconomic influences on biodiversity, ecosystem services and human well-being: a quantitative application of the DPSIR model in Jiangsu, China. Sci Total Environ 490:10121028. https://doi.org/10.1016/j.scitotenv.2014.05.071

Hu H, Liu W, Cao M (2008) Impact of land use and land cover changes on ecosystem services in Menglun, Xishuangbanna, Southwest China. Environ Monit Assess 146(1-3):147-156. https://doi.org/10.1007/s10661-007-0067-7

Hurni H, Wolde-Aregay B, Chadhokar P, Goshu K, Zeleke G, Danano D, Grunder M (2016) Soil and water conservation in ethiopia: Guidlines for development agents. Centre for Development and Environment (CDE). Bern Open Publishing (BOP), Bern, Switzerland

Kandari LS, Yadav HR, Thakur AK, Kandari T (2014) Chat (Catha edulis): a socio economic crop in Harar Region, Eastern Ethiopia. J Korean Phys Soc 3:1-9

Wilbanks TJ, Kates RW (1999) Global change in local places: how scale matters. Climatic Change 43:601-628

Kindu M, Schneider T, Teketay D, Knoke T (2016) Changes of ecosystem service values in response to land use/land cover dynamics in Munessa-Shashemene landscape of the Ethiopian highlands. Sci Total Environ 547:137-147. https:// doi.org/10.1016/j.scitotenv.2015.12.127

Knoke T, Steinbeis OE, Bösch M, Román-Cuesta RM, Burkhardt T (2011) Costeffective compensation to avoid carbon emissions from forest loss: an approach to consider price-quantity effects and risk-aversion. Ecol Econ 70(6):1139-1153. https://doi.org/10.1016/j.ecolecon.2011.01.007

Lambin EF, Geist HJ, Lepers E (2003) Dynamics of land-use and land-cover change in tropical regions. Annu Rev Environ Resour 28(1):205-241. https:// doi.org/10.1146/annurev.energy.28.050302.105459

Le Maitre DC, Gaertner M, Marchant E, Ens EJ, Holmes PM, Pauchard A, Richardson DM (2011) Impacts of invasive Australian acacias: implications for management and restoration. Divers Distrib 17(5):1015-1029. https://doi. org/10.1111/j.1472-4642.2011.00816.x

Li Y, Zhan J, Liu Y, Zhang F, Zhang M (2018) Response of ecosystem services to land use and cover change: a case study in Chengdu City. Resour Conserv Recycl 132:291-300. https://doi.org/10.1016/j.resconrec.2017.03.009

Lin X, Xu M, Cao C, Singh RP, Chen W, Ju H (2018) Land-use/land-cover changes and their influence on the ecosystem in Chengdu City, China during the period of 1992-2018. Sustainability 10:3580

Liu W, Zhan J, Zhao F, Yan H, Zhang F, Wei X (2019) Impacts of urbanizationinduced land-use changes on ecosystem services: a case study of the Pearl River Delta Metropolitan Region, China. Ecol Indic 98:228-238. https://doi. org/10.1016/j.ecolind.2018.10.054

Maitima JM, Mugatha SM, Reid RS, Gachimbi LN, Majule A, Lyaruu H, Pomery D, Mathai S, Mugisha S (2009) The linkages between land use change, land degradation and biodiversity across East Africa. Afr J Environ Sci Technol 3: 310-325

Mamat A, Halik Ü, Rouzi A (2018) Variations of ecosystem service value in response to land-use change in the Kashgar Region, Northwest China. Sustainability 10(1):200. https://doi.org/10.3390/su10010200 
Mekonnen G (2018) Soil characterization, classification and mapping of three watersheds in the Upper Blue Nile basin, Ethiopia. Amhara Design and Supervision Works Enterprise, Bahir Dar, Ethiopia

Milanović M, Knapp S, Pyšek P, Kühn I (2020) Linking traits of invasive plants with ecosystem services and disservices. Ecosyst Serv 42:101072. https://doi.org/1 0.1016/i.ecoser.2020.101072

Negash E, Getachew T, Birhane E, Gebrewahed H (2020) Ecosystem service value distribution along the agroecological gradient in north-central Ethiopia. Earth Syst Environ 4:107-116

Onyekwelu JC, Olabiwonnu AA (2016) Can forest plantations harbour biodiversity similar to natural forest ecosystems over time? Int J Biodivers Sci Ecosyst Serv Manag 12(1-2):108-115. https://doi.org/10.1 080/21513732.2016.1162199

Paquette A, Messier C (2010) The role of plantations in managing the world's forests in the Anthropocene. Front Ecol Environ 8(1):27-34. https://doi.org/1 $0.1890 / 080116$

Putz FE, Redford KH (2010) The importance of defining 'forest': tropical forest degradation, deforestation, long-term phase shifts, and further transitions. Biotropica 42(1):10-20. https://doi.org/10.1111/j.1744-7429.2009.00567.x

Taki H, Yamaura Y, Okabe K, Maeto K (2011) Plantation vs. natural forest: matrix quality determines pollinator abundance in crop fields. Sci Rep 1:132

Tolessa T, Senbeta F, Abebe T (2017a) Land use/land cover analysis and ecosystem services valuation in the central highlands of Ethiopia. For Trees Livelihoods 26(2):111-123. https://doi.org/10.1080/14728028.201 6.1221780

Tolessa T, Senbeta F, Kidane M (2017b) The impact of land use/land cover change on ecosystem services in the central highlands of Ethiopia. Ecosyst Serv 23:47-54. https://doi.org/10.1016/j.ecoser.2016.11.010

Ulya NA, Nurlia A, Kunarso A, Martin E, Waluyo EA (2019) Valuation of goods and services derived from plantation forest in peat swamp forest area: the case of South Sumatra Province. IOP Conf Ser Earth Environ Sci 308: No. 1, p. 012047

van der Ploeg S, de Groot D (2010) The TEEB valuation database-a searchable data-base of 1310 estimates of monetary values of ecosystem services. Wageningen, The Netherlands

Wang X, Dong X, Liu H, Wei H, Fan W, Lu N, Xu Z, Ren J, Xing K (2017) Linking land use change, ecosystem services and human well-being: a case study of the Manas River basin of Xinjiang, China. Ecosyst Serv 27:113-123. https://doi. org/10.1016/j.ecoser.2017.08.013

Wang Y, Dai E, Yin L, Ma L (2018) Land use/land cover change and the effects on ecosystem services in the Hengduan Mountain region, China. Ecosyst Serv 34:55-67. https://doi.org/10.1016/j.ecoser.2018.09.008

Wang Z, Wang Z, Zhang B, Lu C, Ren C (2015) Impact of land use/land cover changes on ecosystem services in the Nenjiang River basin, Northeast China. Ecol Process 4:11. https://doi.org/10.1186/s13717-015-0036-y

Woldemeskel G (1989) The consequences of resettlement in Ethiopia. Oxford Univ Press: $359-374$

Wondie M, Mekuria W (2018) Planting of Acacia decurrens and dynamics of land cover change in Fagita Lekoma district in the northwestern highlands of Ethiopia. Mt Res Dev 38(3):230-239. https://doi.org/10.1659/MRD-JOURNALD-16-00082.1

Wu KY, Ye XY, Qi ZF, Zhang H (2013) Impacts of land use/land cover change and socioeconomic development on regional ecosystem services: the case of fast-growing Hangzhou metropolitan area, China. Cities 31:276-284. https:// doi.org/10.1016/j.cities.2012.08.003

Yang S, Zhao W, Liu Y, Wang S, Wang J, Zhai R (2018) Influence of land use change on the ecosystem service trade-offs in the ecological restoration area: dynamics and scenarios in the Yanhe watershed, China. Sci Total Environ 644:556-566. https://doi.org/10.1016/j.scitotenv.2018.06.348

Ye Y, Bryan BA, Zhang J, Connor JD, Chen L, Qin Z, He M (2018) Changes in land-use and ecosystem services in the Guangzhou-Foshan Metropolitan Area, China from 1990 to 2010: Implications for sustainability under rapid urbanization. Ecol Indic 93:930-941. https:/doi.org/10.1016/j.ecolind.2018.05.031

Yi H, Güneralp B, Filippi AM, Kreuter UP, Güneralp I (2017) Impacts of land change on ecosystem services in the San Antonio River basin, Texas, from 1984 to 2010. Ecol Econ 135:125-135. https://doi.org/10.1016/j.ecolecon.201 6.11 .019

Yibeltal M, Tsunekawa A, Haregeweyn N, Adgo E, Meshesha DT, Aklog D, MasunagaT TM, Billi P, Vanmaercke M, Ebabu K, Dessie M, Sultan D, Liyew M (2019a) Analysis of long-term gully dynamics in different agro-ecology settings. Catena 179:160-174. https://doi.org/10.1016/j.catena.2019.04.013
Yibeltal M, Tsunekawa A, Haregeweyn N, Adgo E, Meshesha DT, Masunaga T, TsuboM BP, Ebabu K, Fenta AA, Berihun ML (2019b) Morphological characteristics and topographic thresholds of gullies in different agroecological environments. Geomorphology 341:15-27

Yuan Y, Wu S, Yu Y, Tong G, Mo L, Yan D, Li F (2018) Spatiotemporal interaction between ecosystem services and urbanization: case study of Nanjing City, China. Ecol Indic 95:917-929. https://doi.org/10.1016/j.ecolind.2018.07.056

\section{Publisher's Note}

Springer Nature remains neutral with regard to jurisdictional claims in published maps and institutional affiliations.

\section{Submit your manuscript to a SpringerOpen ${ }^{\circ}$ journal and benefit from:}

- Convenient online submission

- Rigorous peer review

- Open access: articles freely available online

High visibility within the field

- Retaining the copyright to your article

Submit your next manuscript at $\boldsymbol{\nabla}$ springeropen.com 